\title{
Intrahepatic Bile Duct Cancer Pathologic Regional Lymph Nodes TNM Finding v7
}

National Cancer Institute

\section{Source}

National Cancer Institute. Intrahepatic Bile Duct Cancer Pathologic Regional Lymph

Nodes TNM Finding v7. NCI Thesaurus. Code C90194.

A pathologic finding about one or more characteristics of intrahepatic bile duct cancer, following the rules of the TNM AJCC V7 classification system as they pertain to staging of regional lymph nodes. 